\title{
GEOLOGY OF THE 241-B TANK FARM
}

by

\author{
W. H. Price \\ K. R. Fecht \\ Environmental Engineering Section \\ Research Department \\ Research and Engineering Division
}

\section{Apri1 1976}

ATLANTIC RICHFIELD HANFORO COMPANY RICHLAND, WASHINGTON 99352

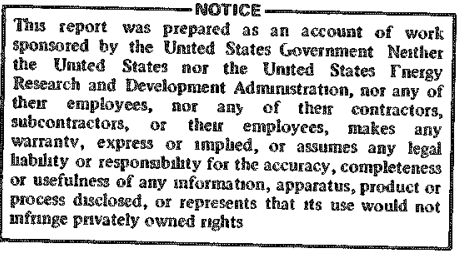

nifringe privately owned rights 


\section{DISCLAIMER}

This report was prepared as an account of work sponsored by an agency of the United States Government. Neither the United States Government nor any agency Thereof, nor any of their employees, makes any warranty, express or implied, or assumes any legal liability or responsibility for the accuracy, completeness, or usefulness of any information, apparatus, product, or process disclosed, or represents that its use would not infringe privately owned rights. Reference herein to any specific commercial product, process, or service by trade name, trademark, manufacturer, or otherwise does not necessarily constitute or imply its endorsement, recommendation, or favoring by the United States Government or any agency thereof. The views and opinions of authors expressed herein do not necessarily state or reflect those of the United States Government or any agency thereof. 


\section{DISCLAIMER}

Portions of this document may be illegible in electronic image products. Images are produced from the best available original document. 
TABLE OF CONTENTS

Page

INTRODUCTION.

PROCEDURES

GENERALIZED GEOLOGY

COLUMBIA RIVER BASALT GROUP .

RINGOLD FORMATION

Middle Ringold.

GLACIOFLUVIAL DEPOSITS

CLASTIC DIKES.

BACKFILL MATERIAL

WATER TABLE

GLOSSARY

SELECTED REFERENCES

LIST OF TABLES

Table

Page

I TANK FARM GEOLOGY DOCUMENTS AVAILABLE AS OF APRIL, 1976。 . 1

II 241-B TANK FARM GEOLOGY MAPS. . . . . . . . . 2

III TYPICAL SIEVE AND CALCIUM CARBONATE VALUES FOR

MIDDLE RINGOLD LITHOLOGY BENEATH 247-B TANK FARM • • • • 7

IV TYPICAL SIEVE AND CALCIUM CARBONATE VALUES FOR EOLIAN SILT LITHOLOGY BENEATH 247-B TANK FARM . . . . . 7

$\checkmark$ TYPICAL SIEVE AND CALCIUM CARBONATE VALUES FOR MAJOR GLACIOFLUVIAL LITHOLOGIES BENEATH 241-B TANK FARM. . . 8

VI TYPICAL SIEVE AND CALCIUM CARBONATE VALUES FOR BACKFILL LITHOLOGY BENEATH 241-B TANK FARM 


\section{LIST OF FIGURES}

Figure

Page

1 STEPS OUTLINING THE PREPARATION OF TANK FARM GEOLOGY MAPS. - 4

2 GENERALIZED STRATIGRAPHIC COLUMN FOR THE 200 AREA TANK FARMS. 5 


\section{GEOLOGY OF THE 241-B TANK FARM}

\section{INTRODUCTION}

A series of maps have been compiled to documerit the stricture and stratigraphy of the sediments underlying the high-level radoacilde wiste storage tank farms located within the Energy Research and Divelopment Administration Hanford Reservation. The primary purpose of these maps is to provide hasic geologic information to be utilized to evaluate the impact of suspected and confirmed tank leaks. For convenience of usage map sets for each tamk farm have been published in separate document packets (see Table I). The cortents of this packet (see Table II) contain maps compiled only for the $241 \mathrm{E}$ Tarl Farm.

TABLE I

TANK FARM GEOLOGY DOCUMENTS AVAILABLE AS OF APRIL, 1976*

\begin{tabular}{ll} 
Title & $\begin{array}{c}\text { Document } \\
\text { Number }\end{array}$ \\
\hline Geology of the 241-A Tank Farm & ARH-LD-127 \\
Geology of the 241-AX Tank Farm & ARH-LD-128 \\
Geology of the 241-B Tank Farm & ARH-LD-129 \\
Geology of the 241-BX Tank Farm & ARH-LD-130 \\
Geology of the 241-BY Tank Farm & ARH-LD-137 \\
Geology of the 241-C Tank Farm & ARH-LD-132 \\
Geology of the 241-S Tank Farm & ARH-LD-133 \\
Geology of the 241-SX Tank Farm & ARH-LD-134 \\
Geology of the 241-T Tank Farm & ARH-LD-135 \\
Geology of the 241-TX Tank Farm & ARH-LD-136 \\
Geology of the 241-TY Tank Farm & ARH-LD-137 \\
Geology of the 241-U Tank Farm & ARH-LD 138 \\
Generalized Geology of the & ARH-LD-139
\end{tabular}

*Additional documents will be completed as new tank farms are built and well monitoring networks installed. 
TABLE II

241-B TANK FARM GEOLOGY MAPS

\section{Title}

241-B Tank Farm Geologic Map Legend and Plot Plan

241-B Tank Farm Geologic Characterization Cross Section $A-A^{\prime}$

241-B Tank Farm Geologic Characterization Cross Section $B-B^{\prime}$

241-B Tank Farm Geologic Characterization Cross Section $C-C^{\prime}$

241-B Tank Farm Geologic Characterization Cross Section D-D'

241-B Tank Farm Geologic Characterization Cross Section E-E'

241-B Tank Farm Geologic Characterization Cross Section F-F'

241-B Tank Farm Geologic Characterization Cross Section G-G' $^{\prime}$

241-B Tank Farm Geologic Characterization Cross Section $\mathrm{H}-\mathrm{H}^{\prime}$

241-B Tank Farm Geologic Characterization Cross Section I-I'

241-B Tank Farm Geologic Characterization Cross Section $\mathrm{J}-\mathrm{J}$ '
Drawing

Number

$H=2-38980$

$H=2.70476$

$H-2-70477$

$H=2-70478$

$11-2-70479$

$H-2-70480$

$H-2-70481$

$H=2-70482$

$H=2-70483$

$H=2-70484$

$H-2-70475$

\section{PROCEDURES}

During the drilling of 27 dry wells and 3 water wells in and around the 241-B Tank Farm, sediment samples were collected from one to 5-foot depth intervals. Information utilized to prepare this series of maps was obtained by the analysis of these samples, numbering approximately 650 . 
Each sediment sample was quantitatively analyzed according to grain size and $\mathrm{CaCO}_{3}$ content. Size analysis was carried out utilizing a nest of 9 sieves selected for coincidence with the Wentworth (1922) grain size nomenclature (see $\mathrm{H}-2-38980$ ). The $\mathrm{CaCO}_{3}$ content of each sample was determined utilizing a semiquantitative $\mathrm{CO}_{2}$ displacenent method (Horwitz, 1970). Size and $\mathrm{CaCO}_{3}$ data was input into the Rocksan Computer Program (Parr, 1974) which categorized each sediment sample into 1 of 19 classes (classification scheme modified after Folk, 1968; see H-2-38980. After analysis, each sample was visually examined to aid in further characterization. Each sample was subsequently stored in the Hanford Well Library for future reference.

For convenience of usage, the geologic maps were prepared at the same scale $\left(7^{\prime \prime}=16^{\prime}\right)$ as drawing $\mathrm{H}-2-36938$ (Wells in 247-B Farm As-bui7t). Steps outlining the preparation of the maps are listed in Figure 7.

\section{GENERALIZED GEOLOGY}

Included within this section is a brief discussion of the geology underlying the 241-B Tank Farm. The stratigraphic descriptions included, along with the Glossary (see page 10), are designed only to provide sufficient information to permit a general understanding of the Tank Farm maps presented. For a more detailed discussion of the regional geologic setting of the 241-T Tank Farm, the reader is referred to articles listed in the Selected References (see page 12).

The 241-B Tank Farm is underlain by four major stratigraphic units (see Figure 2): (1) basalt of the Columbia River Group which forms the bedrock beneath the area; (2) semiconsolidated sediments of the kingold Formation which directly overlie the bedrock; (3) unconsolidated eolian silt; and (4) unconsolidated sand, silt, and gravel, collectively termed glaciofluvial sediments, which directly overlie the colian silt. A more detailed description of the character of these units underlying the Tank Farm follows. 


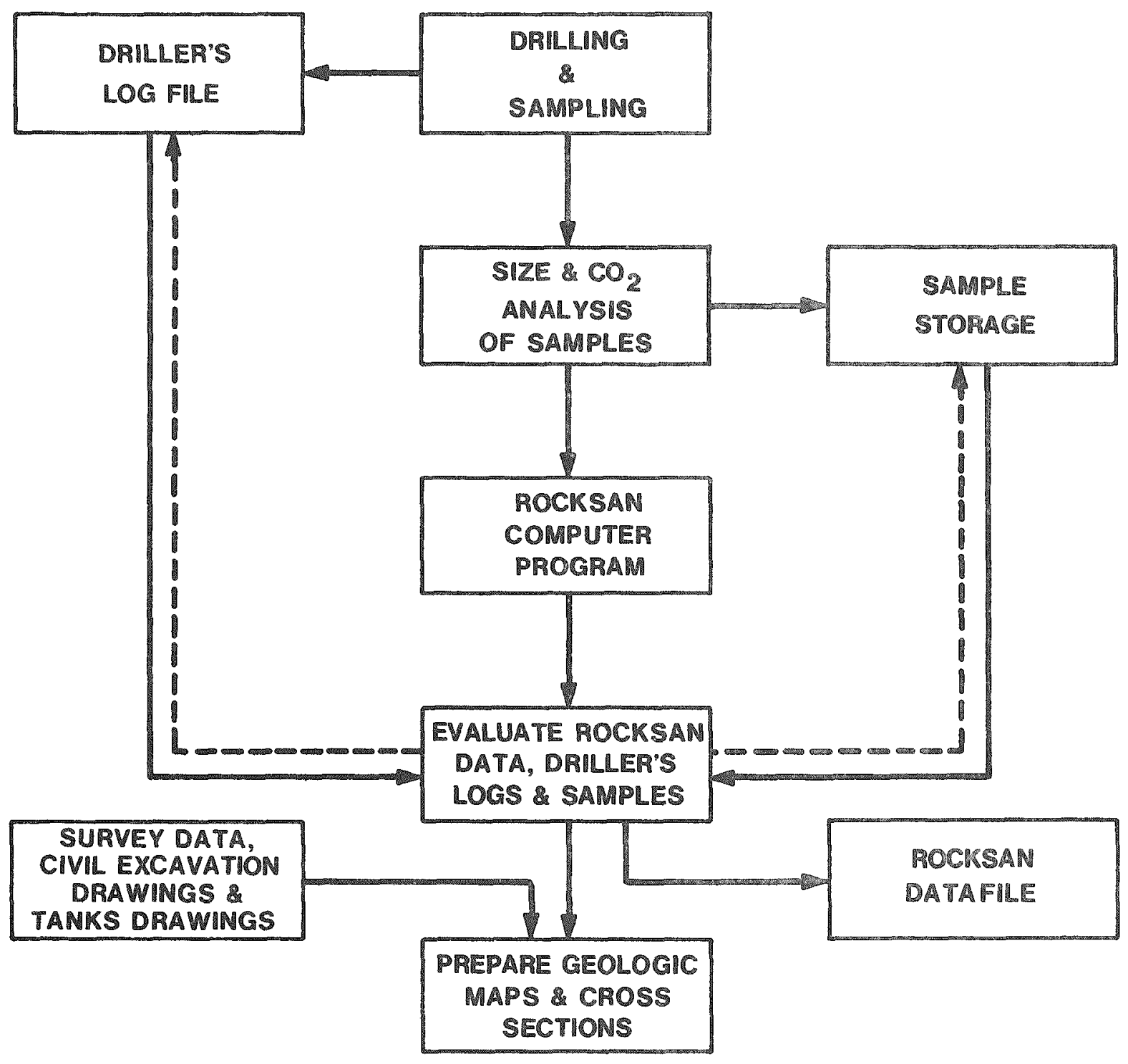

FIGURE 1

STEPS OUTLINING THE PREPARATION OF

TANK FARM GEOLOGY MAPS 


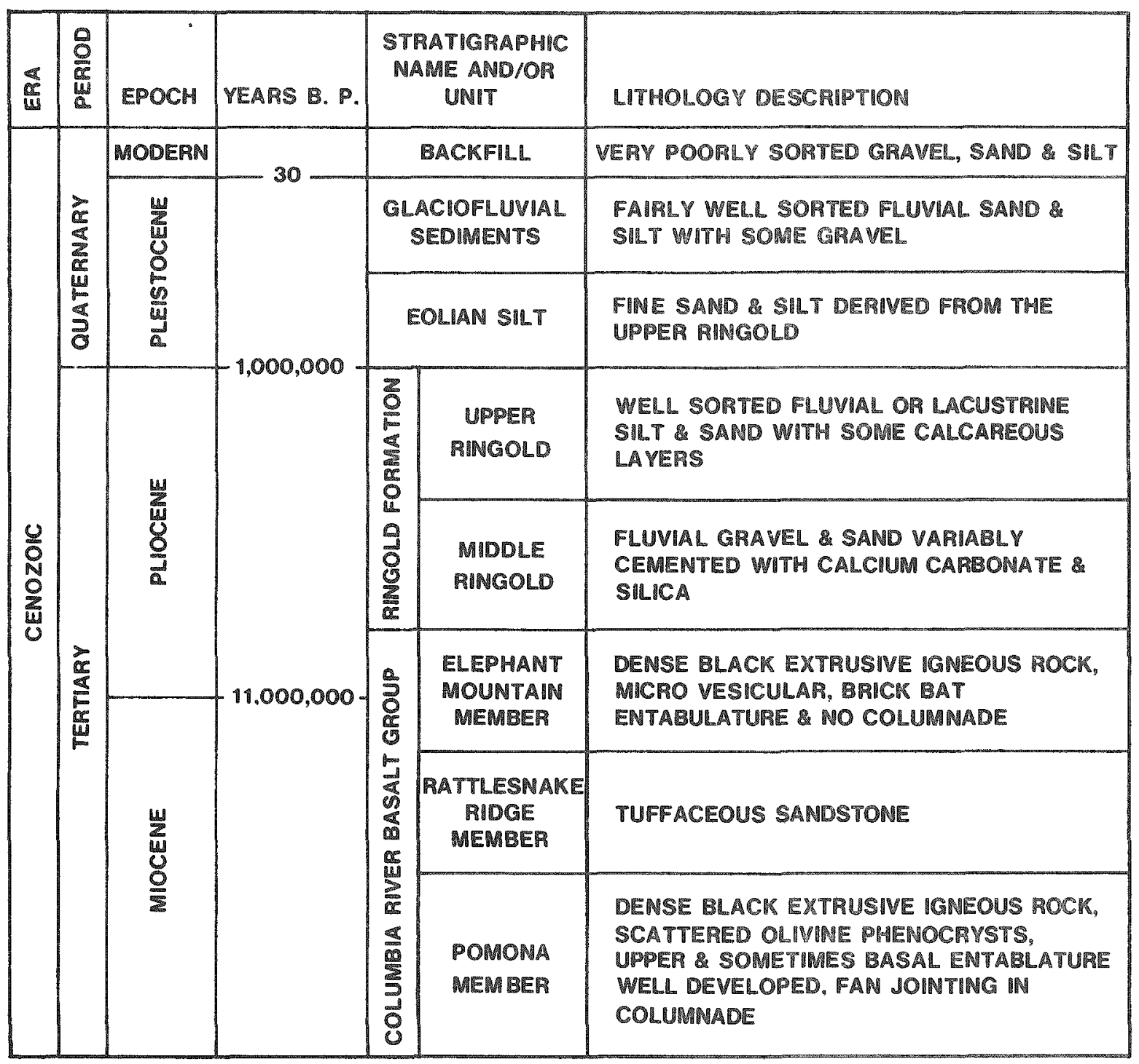

WHP/KRF 1976

FIGURE 2

GENERALIZED STRATIGRAPHIC COLUMN FOR THE 200 AREA TANK FARMS 
COLUMBIA RIVER BASALT GROUP

About 20 million years ago a series of fissures opened around the periphery of the subsiding Pasco Basin and large volumes of basaltic lava poured out over the land surface. The highly fluid lava was extruded intermittently from these fissures until approximately 8 million years ago. At the cessation of Columbia River Basalt volcanism, the basin had been filled with more than 12,000 feet of basalt.

The surface of the Columbia River Basalt lies beneath 241-B Tank Farm at an elevation of 366 feet (a1) elevations based on feet above mean sea level measured at approximate center of Tank Farm).

\section{RINGOLD FORMATION}

Following the cessation of Columbia River Basalt volcanism the ancestral Columbia River transported sediments from the surrounding highlands into the Pasco Basin where they accumulated to form the Ringold Formation. Beneath the Hanford Reservation, this formation is up to 1200 feet thick and can generally be divided into three units on the basis of lithology; the clays and silts of the lower Ringold unit; the pebbles and cobbles of the middle Ringold unit; and the silts and fine sands of the upper Ringold unit.

Within the region beneath 241-B Tank Farm, the lower and upper Ringold units are missing. The totai thickness of the middle Ringold unit present is approximately 26 feet.

\section{Middle Ringold}

Beneath the 241-B Tank Farm, middle Ringold unit lies unconformably on the Columbia River Basalt and dips about one degree to the southeast. The unit consists predominantly of well-rounded pebbles and cobbles with the interstitial spaces filled with very coarse to coarse sand. Table III summarizes the grain size and $\mathrm{CaCO}_{3}$ values of the middle Ringold sediments. 
TABLE III

TYPICAL SIEVE AND CALCIUM CARBONATE

VALUES FOR MIDDLE RINGOLD LITHOLOGY

BENEATH 241-B TANK FARM

Lithology

Sirty Sandy Coarse to Very Fine Pebble to Pebbly Silty

Very Coarse to

Coarse Sand

\section{EOLIAN SILT DEPOSIT}

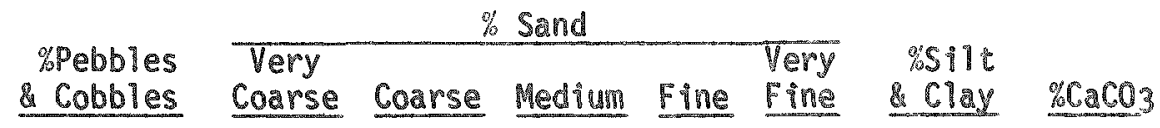

32

17

10

64

8

0.6

After deposition of the Ringold Formation, the surface of the land was subjected to subaerial erosion. Wind action winnowed, reworked, and redeposited the fine grained sands and silts of the nearby upper Ringoid unit. These wind-deposited sediments, termed Early Palouse soil or eolian silt, occur beneath the 247-B Tank Farm between elevations 392 and 432 feet. Table IV summarizes the grain size and $\mathrm{CaCO}_{3}$ content of the eolian silt.

\section{TABLE IV}

TYPICAL SIEVE AND CALCIUM CARBONATE VALUES

FOR EOLIAN SILT LITHOLOGY

BENEATH 241-B TANK FARM

\begin{tabular}{|c|c|c|c|c|c|c|c|c|}
\hline \multirow[b]{2}{*}{ Lithology } & \multirow[b]{2}{*}{$\begin{array}{r}\text { \%pebbles } \\
\text { \& Cobbles }\end{array}$} & \multicolumn{5}{|c|}{$\%$ Sand } & \multirow[b]{2}{*}{$\begin{array}{r}\text { \%SIlt } \\
\& \text { Clay }\end{array}$} & \multirow[b]{2}{*}{$\% \mathrm{CaCO}$} \\
\hline & & $\begin{array}{l}\text { Very } \\
\text { Coarse }\end{array}$ & Coarse & Medium & Fine & $\begin{array}{l}\text { Very } \\
\text { Fine }\end{array}$ & & \\
\hline $\begin{array}{l}\text { Silty Very Fine } \\
\text { Sand to Sandy Silt }\end{array}$ & 0 & 2 & 3 & 3 & 4 & 40 & 48 & 20 \\
\hline
\end{tabular}

\section{GLACIOFLUVIAL DEPOSITS}

During the close of the Ice Age, approximately 20,000 years ago, a continental ice sheet covered much of northern Washington. As the ice sheet retreated northward, the breakup of ice dams resulted in catastrophic floods in which large volumes of glacial meltwater were released. During one of these floods, over 500 cubic miles of water is estimated to have poured into the Pasco Basin at a rate of more than 9 cubic miles of water 
per hour. Sediments deposited within the basin by such flooding now comprise the glaciofluvial unit. The characteristic variability of sediment size and degree of sorting within this unit can be attributed to changes in water velocity and water level which occurred during the flooding process.

Glaciofluvial deposits are found beneath the 241-B Tank Farm between elevations 432 and 614 feet. The 182 -foot thick section of these deposits consists predominentiy of very coarse to medium sand with some silt and pebbles. Table $V$ summarizes the grain size and $\mathrm{CaCO}_{3}$ values of the glaciofluvial sediments.

TABLE $V$

TYPICAL SIEVE AND CALCIUM CARBONATE VALUES FOR MAJOR GLACIOFLUVIAL LITHOLOGIES BENEATH 241-B TANK FARM

\begin{tabular}{|c|c|c|c|c|c|c|c|c|}
\hline \multirow[b]{2}{*}{ Lithology } & \multirow[b]{2}{*}{$\begin{array}{r}\text { \%ebbles } \\
\text { \& Cobbles } \\
\end{array}$} & \multicolumn{5}{|c|}{$\%$ Sand } & \multirow[b]{2}{*}{$\begin{array}{r}\% 511 t \\
\text { \& Ciay } \\
\end{array}$} & \multirow[b]{2}{*}{$\therefore \mathrm{CaCO}$} \\
\hline & & $\begin{array}{l}\text { Very } \\
\text { Coarse } \\
\end{array}$ & Coarse & Medium & Fine & $\begin{array}{l}\text { Very } \\
\text { Fine }\end{array}$ & & \\
\hline $\begin{array}{l}\text { Slightly Pebbly } \\
\text { Very Coarse to } \\
\text { Coarse Sand to } \\
\text { Very Coarse to } \\
\text { Coarse Sand }\end{array}$ & 6 & 35 & 31 & 10 & 4 & 3 & 4 & 1.3 \\
\hline $\begin{array}{l}\text { Slightly Silty } \\
\text { Very Coarse to } \\
\text { Coarse Sand to } \\
\text { slightly Pebbly } \\
\text { slightly Silty } \\
\text { Very Coarse to } \\
\text { Coarse Sand }\end{array}$ & 5 & 31 & 22 & 16 & $\pi$ & 5 & 10 & 1.4 \\
\hline
\end{tabular}

\section{CLASTIC DIKES}

Throughout the Pasco Basin, clastic dikes are found cross-cutting the Ringold Formation and glaciofluvial sediments. These dikes, which range from a few inches to several feet in width, are known to exist to depths of more than 100 feet below the ground surface. Generally, the dikes are composed fine silts to coarse sands. The origin of the clastic dikes is still in refute and will not be discussed here (see selected References). 
Identification of clastic dikes by drilling is difficult and although some dikes were detected in the 241-B Tank Farm, they could not be mapped.

\section{BACKFILL MATERIAL}

In preparation for tank construction, glaciofluvial material was excavated at the 241-B Tank Farm site. This material, consisting predominantiy of cobbles, pebbles, and very coarse to medium sands with some silt, was subsequently used as backfill from the base of the completed tanks (614 feet) to the ground surface (653 feet). An inherent characteristic of the backfill is its poor sorting. Grain size and $\mathrm{CaCO}_{3}$ values for the backfill are found in Table VI.

TABLE VI

TYPICAL SIEVE AND CALCIUM CARBONATE

VALUES FOR BACKFILL LITHOLOGY

BENEATH 241-B TANK FARM

\begin{tabular}{|c|c|c|c|c|c|c|c|c|}
\hline \multirow[b]{2}{*}{ Lithology } & \multirow[b]{2}{*}{$\begin{array}{r}\text { qPebbles } \\
\text { \& Cobbles }\end{array}$} & \multicolumn{5}{|c|}{$\%$ Sand } & \multirow[b]{2}{*}{$\begin{array}{r}8511 t \\
\text { Clay } \\
\end{array}$} & \multirow[b]{2}{*}{$\because \mathrm{CaCO}$} \\
\hline & & $\begin{array}{l}\text { Very } \\
\text { Coarse }\end{array}$ & Coarse & Medium & Fine & $\begin{array}{l}\text { Very } \\
\text { Eine }\end{array}$ & & \\
\hline $\begin{array}{l}\text { Silty Sandy Gravel } \\
\text { to Sandy Grave? }\end{array}$ & 49 & 16 & 12 & 9 & 4 & 3 & 7 & 1.3 \\
\hline
\end{tabular}

\section{WATER TABLE}

The water table beneath the 247-B Tank Farm is located within the middle Ringold unit at an elevation of 403 feet, 211 feet below the base of the tanks. For further information concerning contours on the water table beneath 200 East Area the reader is referred to drawings $H=2-38398$ (200 East Area Water Table Map) and H-2-38399 (200 East Area Depth to Water Map). 


\section{GLOSSARY}

Basalt. Fine-grained, dark-colored, extrusive igneous rock.

Calcareous. Containing calcium carbonate.

Caliche. Gravel, sand, or silt cemented by calcium carbonate.

Cement. Chemically precipitated material occurring in the interstices between particles of gravel, sand, or silt.

Clastic. A textural term applied to rocks composed of fragmental material derived from pre-existing rocks.

Clastic dike. A tabular body of clastic material transecting the bedding of a sedimentary formation, representing extraneous material that has invaded the containing formation along a crack.

Dip. The angle at which a stratum or any planar feature is inclined from the horizontal.

Eolian. A formation formed by, or deposited from, the wind or currents of air.

Fluvial. Produced by the action of a river or stream.

Formation. The ordinary unit of geologic mapping consisting of a large and persistent stratum of some one kind of rock.

Glaciofluvial. Pertaining to streams flowing from glaciers or to the deposits made by such streams.

Grain. The particles or discrete crystals which comprise a rock or sediment.

Group. A local or provincial subdivision of a series, based on lithologic features and contains two or more formations.

Lacustrine. A formation deposited in a lake environment.

Lava. Fluid rock such as that which issues from a volcano or a fissure in the earth's surface and the same material solidified by cooling.

Lithology. The description of rocks or sediments on the basis of such characteristics as color, minerologic composition and grain size.

Sediment. Descriptive term for grave1, sand, and silt transported from their sources and deposited by air, water, or ice.

Sieve. A utensil having many small perforated openings, used to separate fine particles from coarser ones. 
Siliceous. Containing silica.

silt. Fine grained material between sand and clay in size.

Sorting. The grain size range of the sediments.

Stratigraphy. The part of descriptive geology of an area that pertains to the discrimination, character, thickness, sequence, age and correlation of the sediments and rocks of the area.

Subaerial. Formed, existing, or taking place on the land surface.

Unconformity. A surface of erosion or nondeposition that separates younger strata from older strata.

Water table. The upper surface of a zone of saturation except where that surface is formed by an impermeable body.

Winnowing. Separation of fine particles from coarser ones by wind action. 


\section{SELECTED REFERENCES}

1. J. A. Alwin, Clastic Dikes of Touchet Beds, Southeastern Washington, Washington State University Masters Thesis (1970).

2. V.R. Baker, Paleohydrology and Sedimentology of Lake Missoula Floouing in Eastern Washington, GeoTogical Society of America Special Paper T44. (1973).

3. J. H. Bretz, Washington's Channeled Scabland, Washington Division of Mines and Geology, BuT7. 45, (1959).

4. D. J. Brown, Subsurface Geology of the Hanford Separations Areas, HW $-61780(1959)$.

5. D. J. Brown, An Eolian Deposit Beneath 200 West Area, HW-67549 (1960).

6. D. J. Brown, and R. E. Brown, Touchet Clastic Dikes in the Ringold Formation, HW-SA-2851 (1962).

7. D. J. Brown, G. T. Lobdell, and G. E. Neff, Hydrology and Engineering Geology of the Columbia Basin, Geological Society of America, CordilTeran Section, 72nd Annual Meeting, Field Guide No. 3 (1976).

8. R. L. Folk, "Petrology of Sedimentary Rocks," University of Texas Press (1968).

9. R. Fryxel1, and E. F. Cook, A Field Guide to the Loess Deposits and Channeled Scablands of the PaTouse Area, Eastern Washington, Laboratory of Anthropology Report 27, Pullman, Washington (1964).

10. E. H. Gilmour, and D. Stradiing, Proceedings of the Second Columbia River Basalt Symposium. EWSC Press, Cheney, Washington (1969).

11. E. Gustafson, A Revised Chronology for Vertebrate Fossil Faunas of Eastern Washington, Geological Society of America, CordilTeran Section. 72nd Annual Meeting (1976).

12. W. Horwitz, Official Methods of Analysis of the Association of official Analytical Chemists, 17 th Edition, Association of Official Analytical Chemists, p. 139, (1970).

13. R. K. Ledgerwood, D. J. Brown, C.W. Meyers, and A. C. Waters, Identification of Yakima Basalt Flows in the Pasco Basin, ARH-27-68 (1973).

14. R. L. Lupher, Clastic Dikes of the Columbia Basin Region, Washington and Idaho, Geological Society of America BuIT., V55, 1437-7462 (1944). 
15. M. W. McGoniea, Deformation of the Ringold Formation, HW-36373 (1955).

16. B. Mckee, Cascadia the Geologic Evolution of the Pacific Northwest, McGraw-Hill Book Co. (1972).

17. R. C. Newcomb, J.R. Strand, and F. J. Frank, Geology and Groundwater Characteristics of the Hanford Reservation of the U.S. Atomic Eneroy Commission, Washington, U. S. Geological Survey Prof. Paper 717 (1972).

18. J. M. Parr, Sieve Analysis Program, Atlantic Richifield Hanford Company, Unpubtished.

19. G. D. Webster, V.R. Barber, and C. Gustafson, Channeled Scabland of Southeastern Washington A Road Log Via Spokane - CouTee City - Vantage Washtucna - Lewiston - Pullman, Geological Society of America, Cordilieran Section, 72 nd Annual Meeting, Field Guide No. 2 (1976).

20. C. K. Wentworth, A Scale of Grade and Class Terms for clastic Sediments, Journal of Geology, V. 30, 377-392 (1922). 
DISTRIBUTION

Energy Research and Development

Administration - Richland Operations office

0.J. Elgert Fed 700

J.A. Fernandez Fed 700

A.G. Lasila Fed 700

Battelle-Northwest

R.L. Brodzinski

J.R. Eliason

V.L. McGhan

S.J. Phillips

J. Raymond

R.W. Wallace

Atlantic Richfield Hanford Company

\section{B.W. Anderson}

J. Anderson

H. Babad

G.E. Backman

L.D. Bockstanz

D.G. Bouse

D.J. Brown

L.E. Bruns

G. Burton, Jr.

R.A. Deju

F.R. Dornheim

G.T. Dukelow

P.G. Easley

K.R. Fecht

R.D. Fox

D.G. Harlow

W.M. Harty

O.F. Hill

H.F. Jensen

M.W. Legatski

B.J. McMurray

P.W. Metz

W.H. Price (2)

R.C. Roal

B.J. Saueressig

V.D. Schrag

H.P. Shaw

J.A. Teal

R.E. Van der Cook

R.L. Waiser 


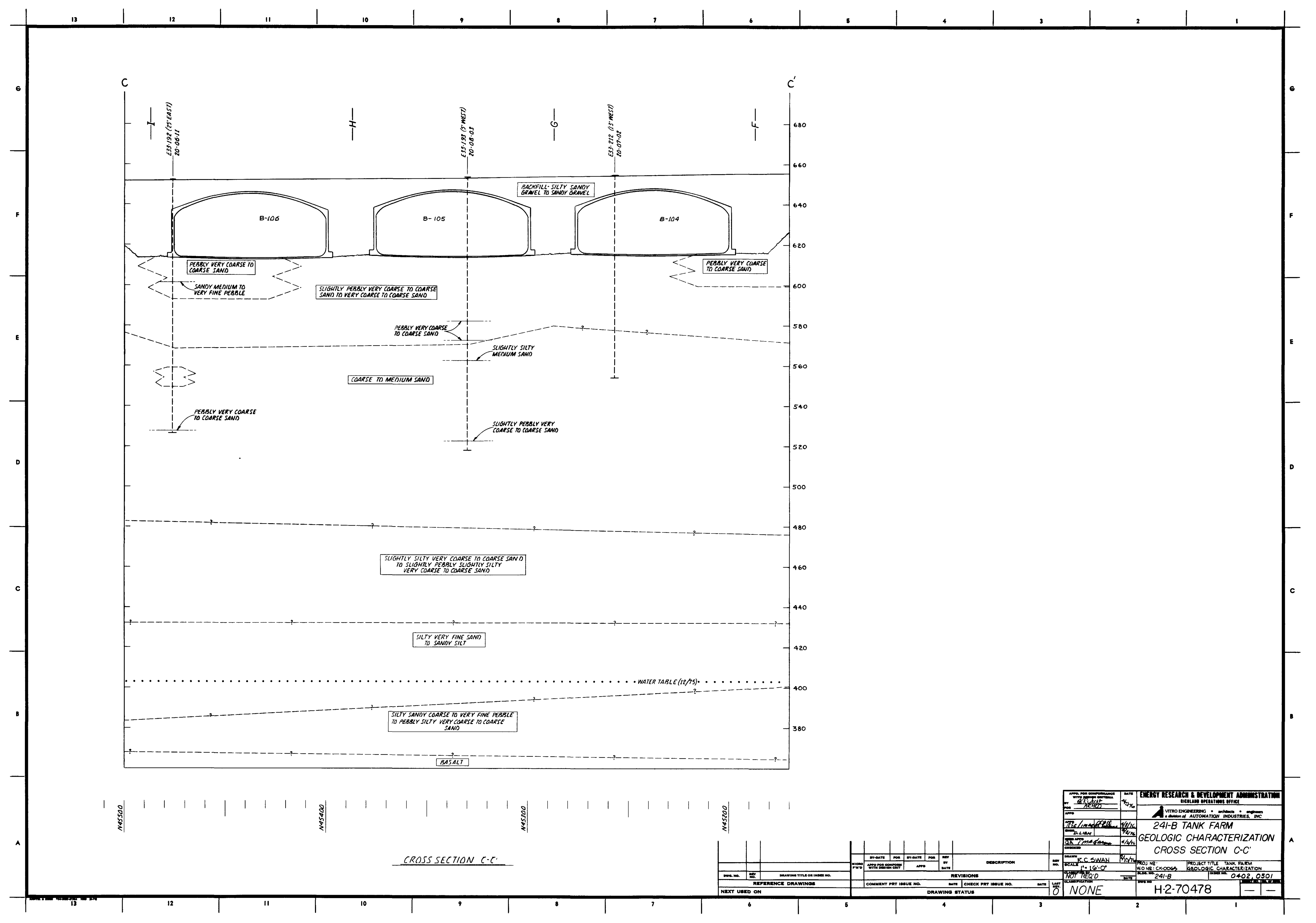




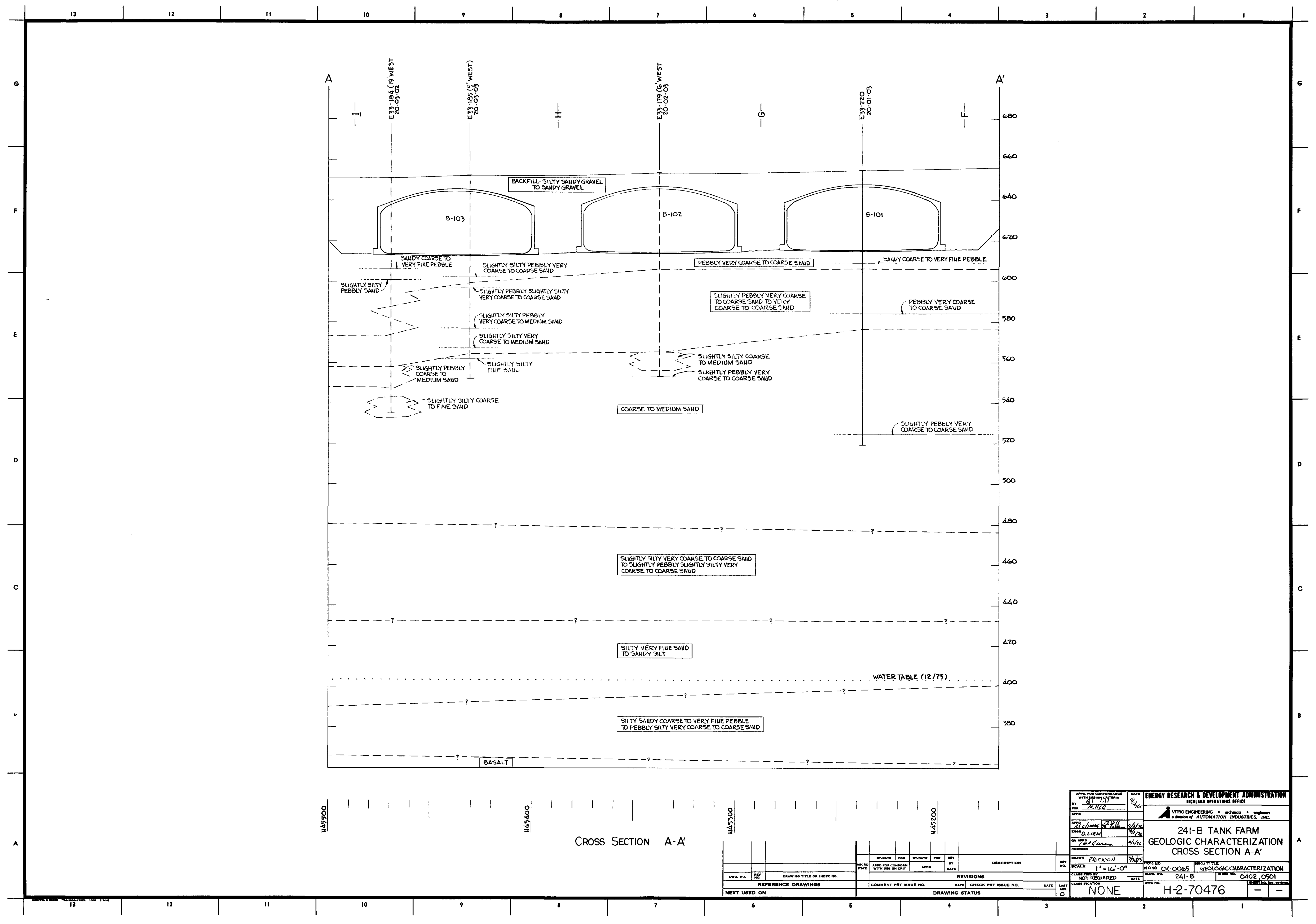




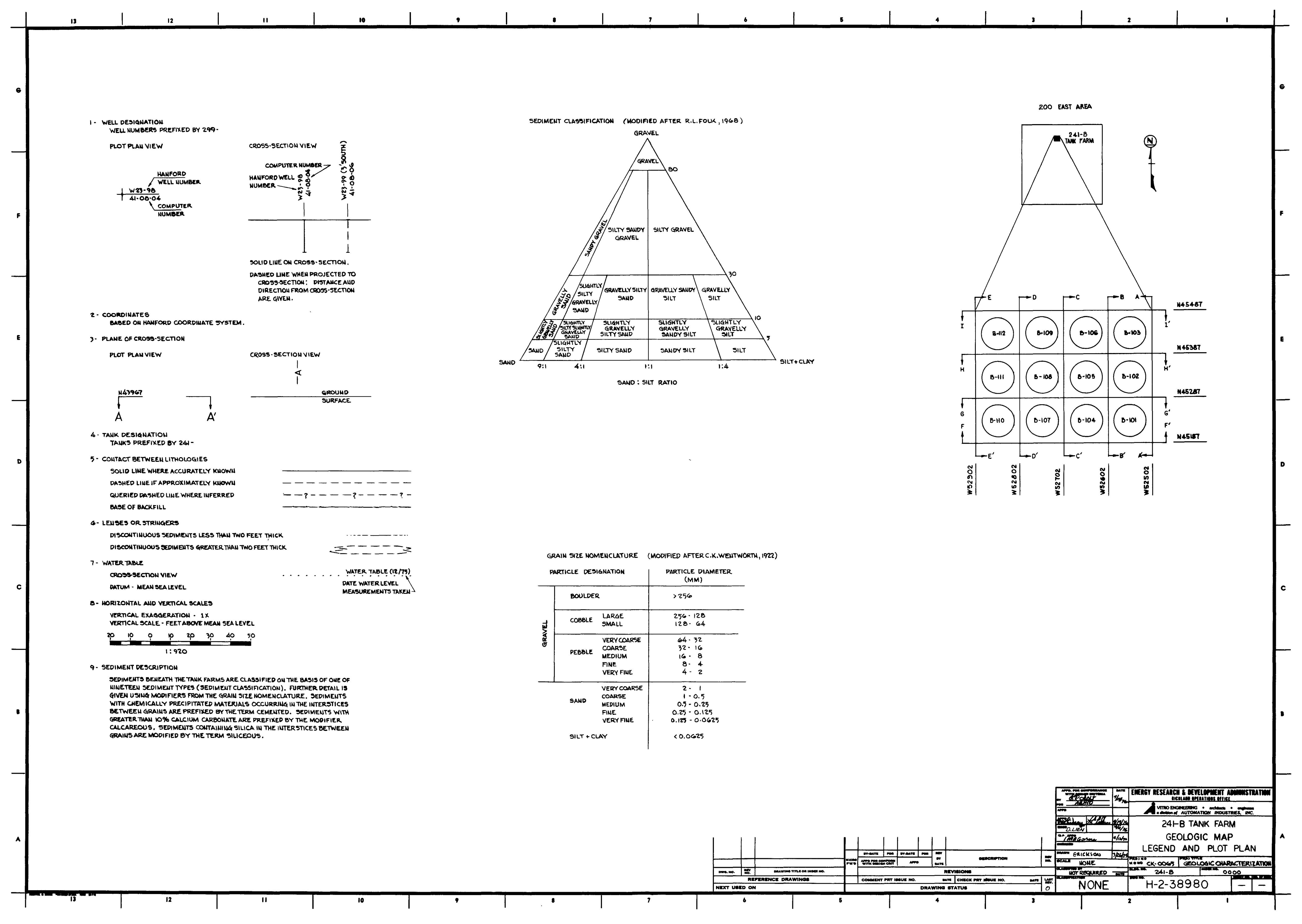




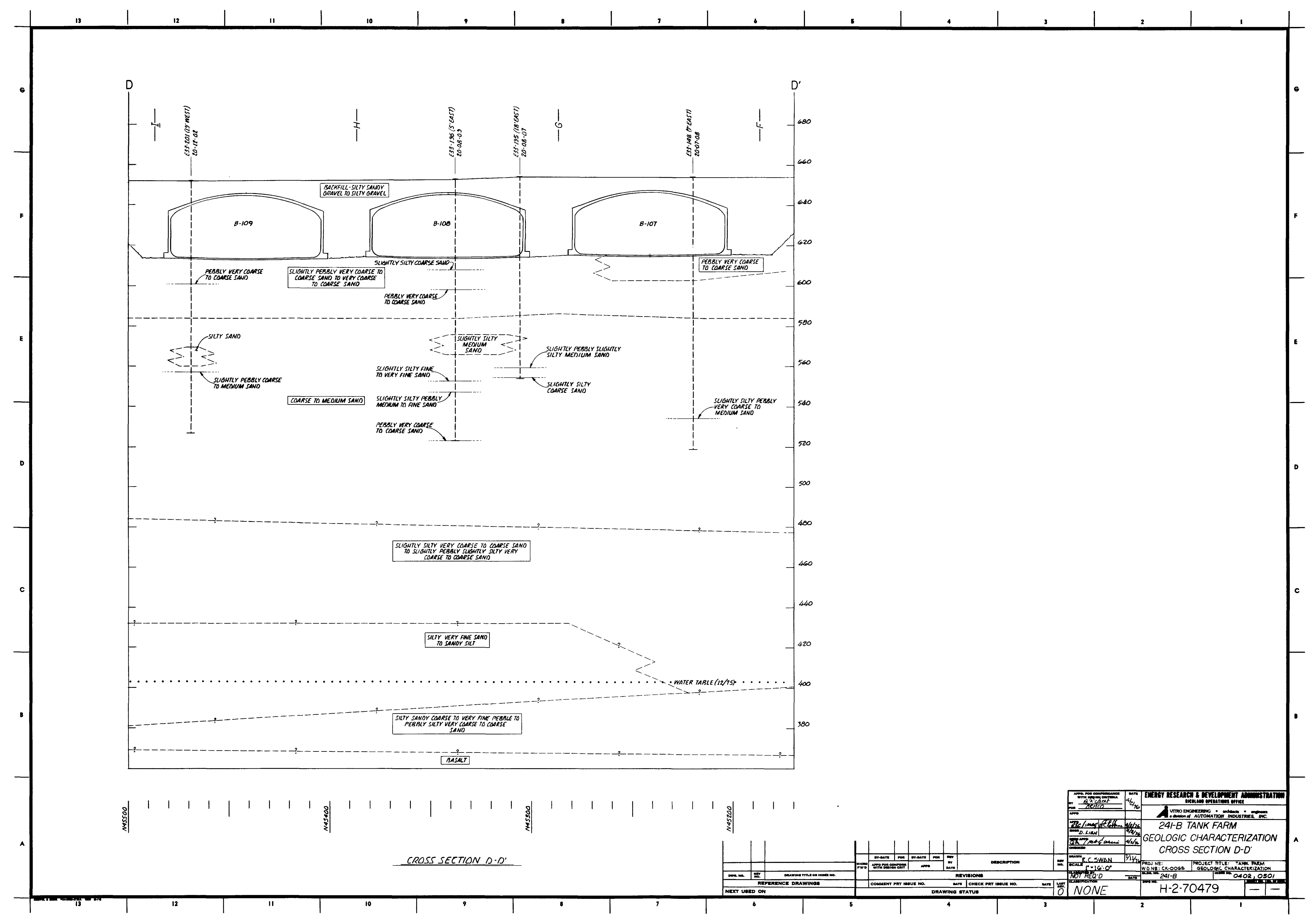




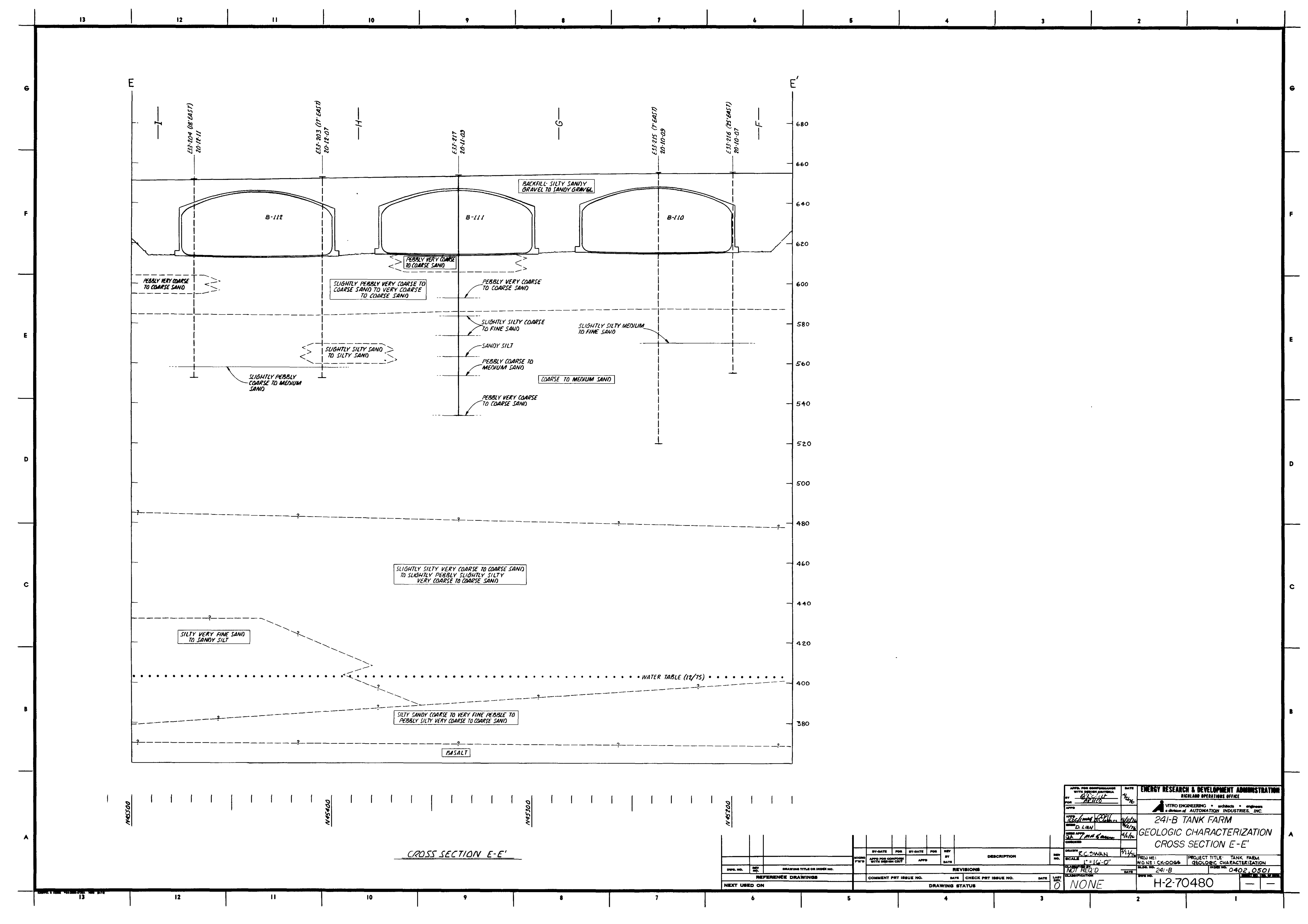



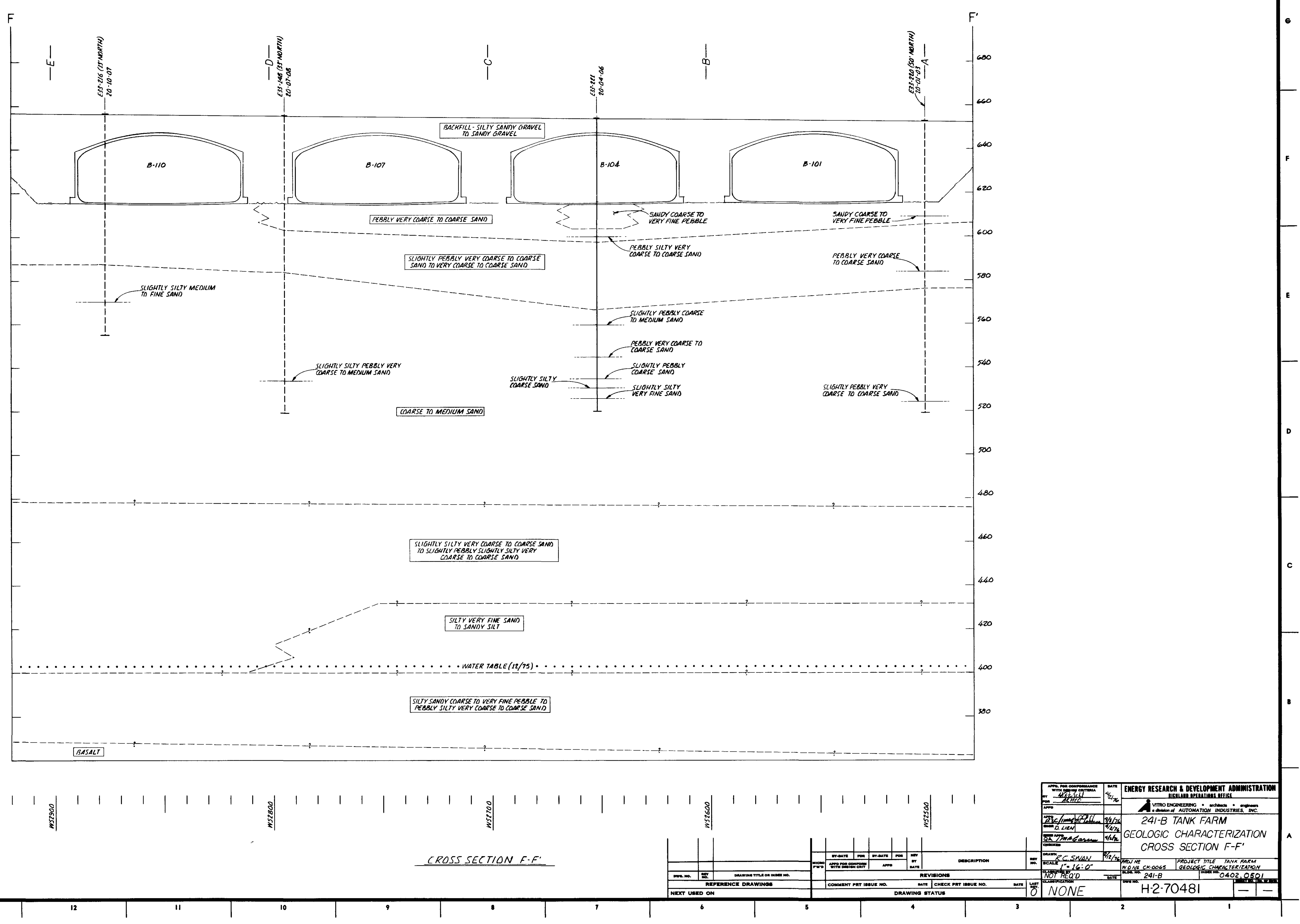


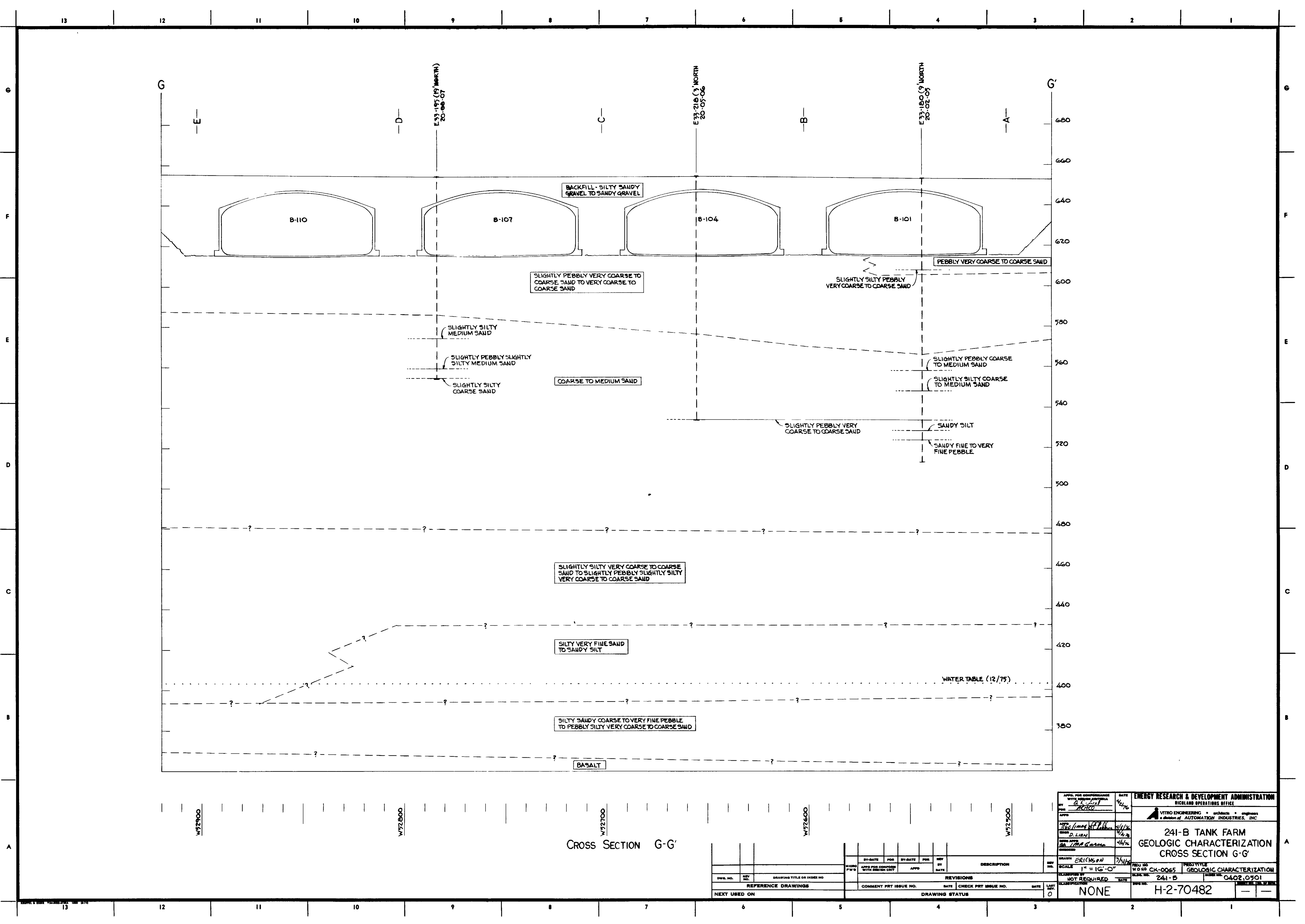




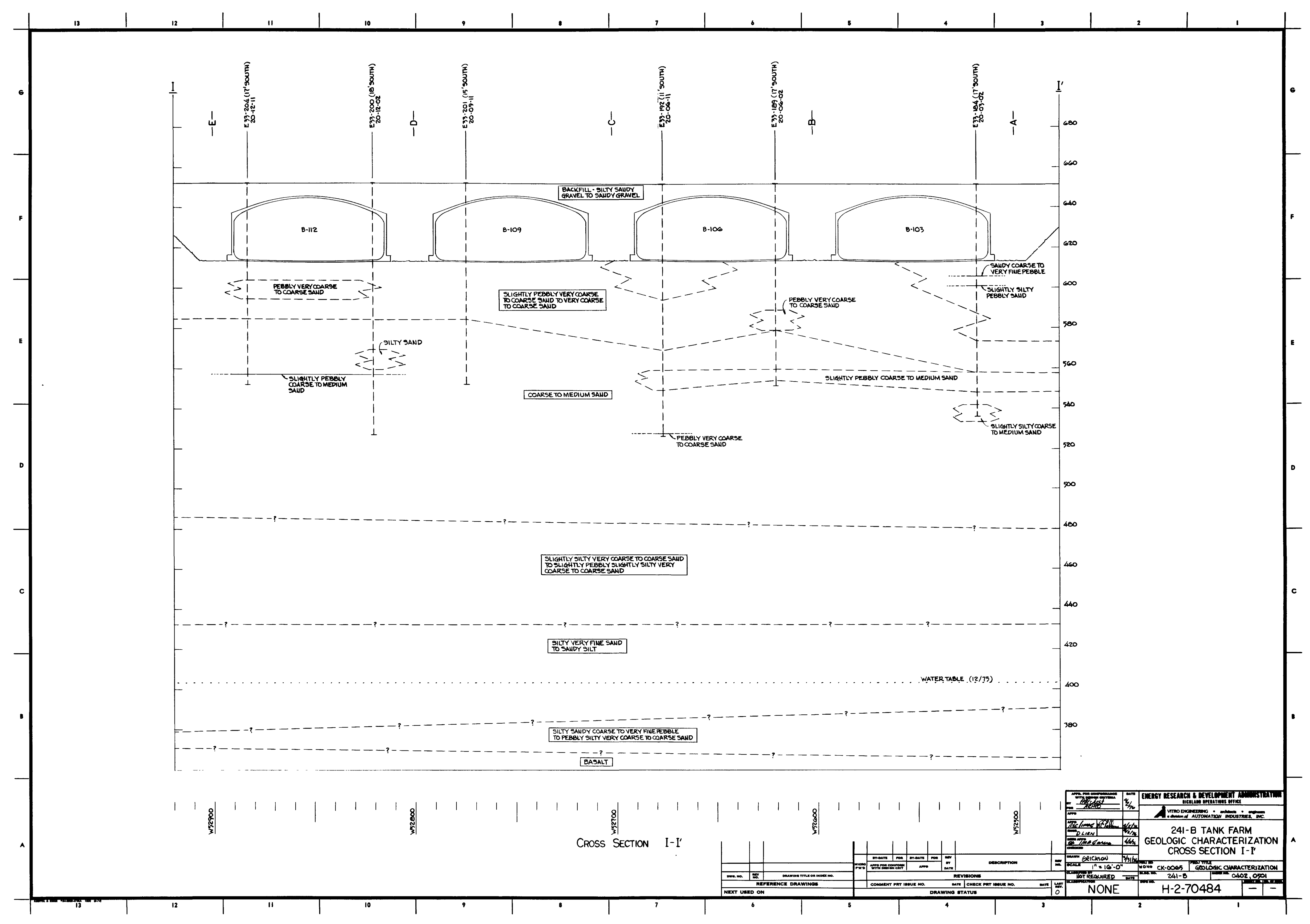




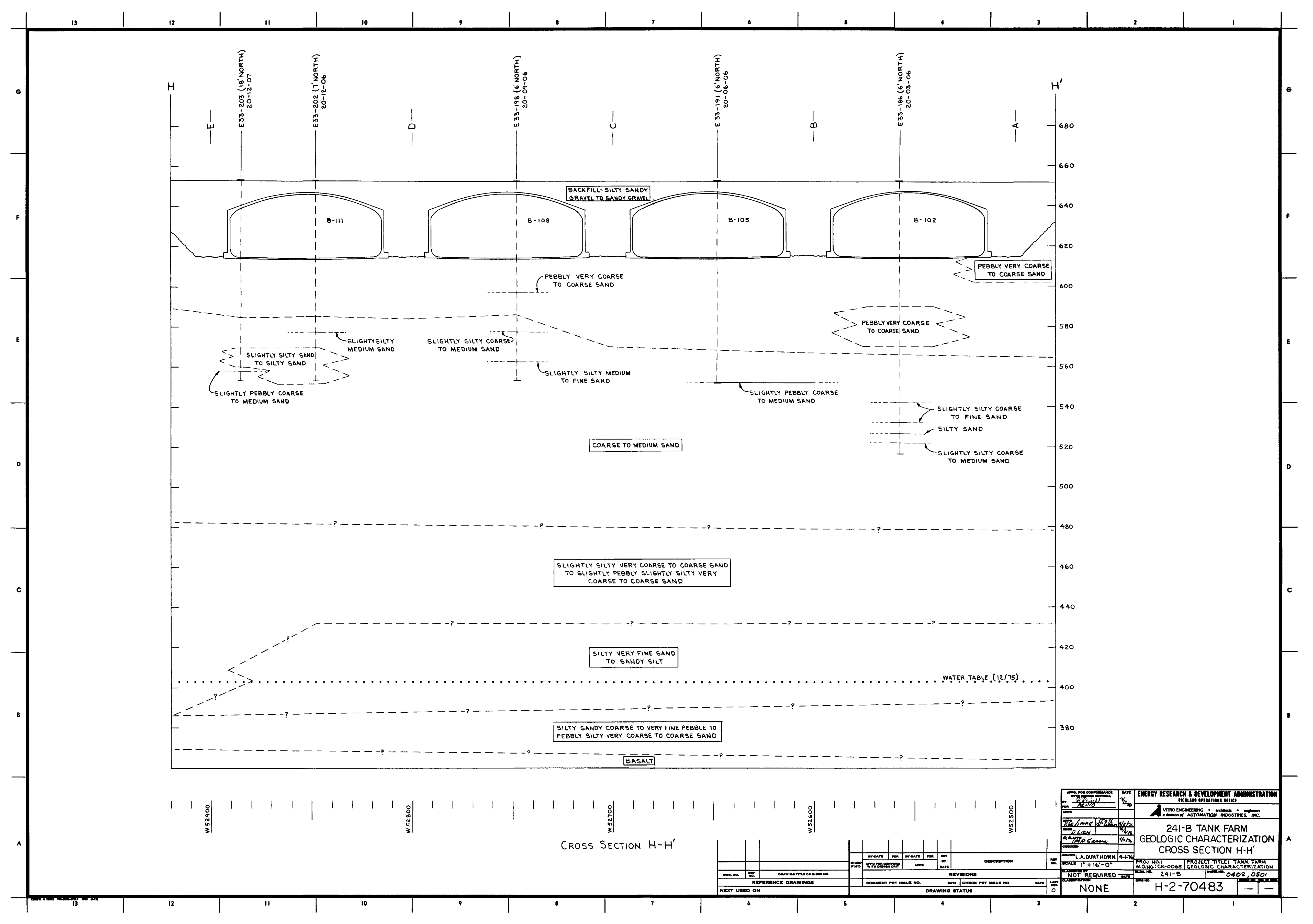




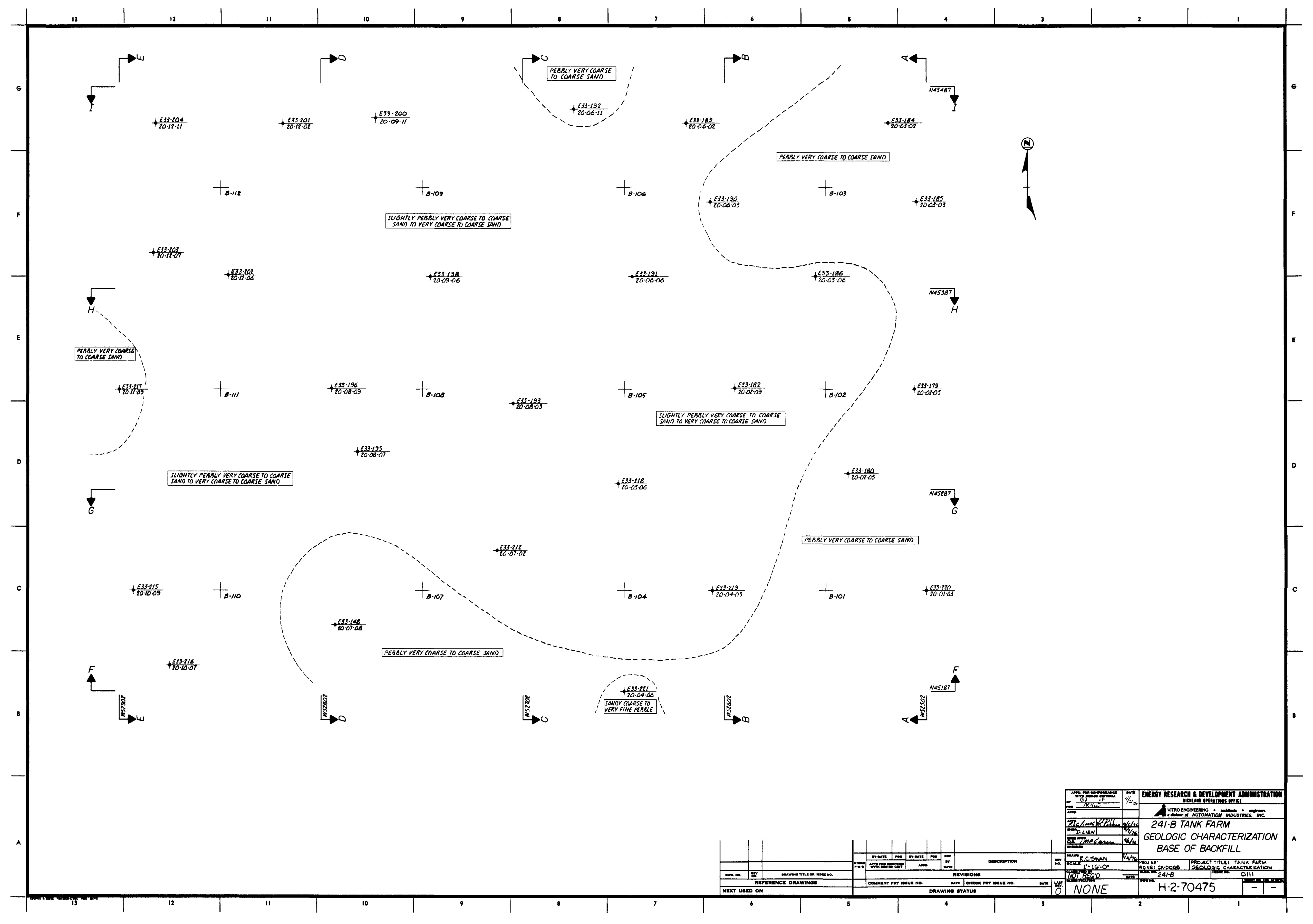

